\title{
Kredit Rentenir dan Silaturahmi
}

\section{Loan Sharks and Friendly Associations}

\author{
Novita Rahayu Pratiwi ${ }^{1)}$, Maretha Ika Prajawati ${ }^{2)}$, Basir $\mathbf{S}^{3)}$ \\ ${ }^{1,2)}$ Fakultas Ekonomi, UIN Maulana Malik Ibrahim, Malang \\ ${ }^{3)}$ Sekolah Kajian Stratejik dan Global, Universitas Indonesia, Jakarta \\ e-mail korespondensi: novitarahayupratiwi@gmail.com
}

\begin{tabular}{|c|c|}
\hline Info $\mathrm{A}$ & \multirow{3}{*}{$\begin{array}{l}\text { Penelitian ini memiliki tujuan untuk menganalisis makna hutang menurut } \\
\text { masyarakat Kampung Kauman yang lebih memilih rentenir daripada bank } \\
\text { sebagai sumber kredit mereka. Penelitian kualitatif ini menggunakan studi kasus. } \\
\text { Data primer diperoleh melalui hasil wawancara dengan warga Kampung } \\
\text { Kauman Desa Pasrepan Kabupaten Pasuruan Jawa Timur, yang terletak di } \\
\text { lingkungan pondok pesantren dengan tipe masyarakat yang agamis. Data } \\
\text { sekunder berupa rincian sistem kredit pada rentenir. Sampel yang digunakan } \\
\text { bersifat jenuh, yaitu semua yang menjadi anggota kredit pada rentenir. Total } \\
\text { informan berjumlah } 21 \text { dari } 30 \text { kepala keluarga di Kampung Kauman. Hasil } \\
\text { penelitian ini menunjukkan bahwa makna kredit pada rentenir bagi masyaraat di } \\
\text { lingkungan situs penelitian adalah modal usaha, wadah bersilaturahmi, saling } \\
\text { meringankan antar anggota kredit, serta mengenai hukum riba pada kredit. } \\
\text { Kata Kunci: Kredit, Rentenir, Bias Psikologis, Perilaku Keuangan, Agamis. }\end{array}$} \\
\hline $\begin{array}{l}\text { Mel : } \\
\text { Mei } 2020\end{array}$ & \\
\hline $\begin{array}{l}\text { Nomor DOI } \\
\text { 10.33059/jseb.v12i1.2296 } \\
\text { Cara Mensitasi : } \\
\text { Pratiwi, N.R., Prajawati, M.I., } \\
\text { \& Basir S. (2021). Kredit } \\
\text { rentenir dan silaturahmi. } \\
\text { Jurnal Samudra Ekonomi dan } \\
\text { Bisnis, 12(1), 102-116. doi: } \\
\text { 10.33059/jseb.v12i1.2296. }\end{array}$ & \\
\hline & \multirow{4}{*}{$\begin{array}{l}\text { Abstract } \\
\text { The study aims to analyze the meaning of debt according to the people of } \\
\text { Kampung Kauman who prefer moneylenders than banks as their source of } \\
\text { credit. This qualitative research uses a case study. Primary data were obtained } \\
\text { through interviews with residents of Kampung Kauman, Pasrepan Village, } \\
\text { Pasuruan Regency, East Java, which is located in an Islamic boarding school } \\
\text { environment with a religious type of community. Secondary data in the form of } \\
\text { details of the credit system to moneylenders. The sample used is saturated, i.e. } \\
\text { all those who are credit members to loan sharks. Total informants numbered } 21 \\
\text { of } 30 \text { households in Kauman Village. The results of this study indicate that the } \\
\text { meaning of credit to loan sharks for the community in the study site } \\
\text { environment is venture capital, a friendly place of association, mutual relief } \\
\text { among credit members, and regarding usury laws on credit. } \\
\text { Keywords: Loan, Moneylenders, Psychological Bias, Financial Behavior, } \\
\text { Religious. }\end{array}$} \\
\hline & \\
\hline & \\
\hline & \\
\hline
\end{tabular}




\section{PENDAHULUAN}

Kabupaten Pasuruan terletak di wilayah geografis $112^{\circ} 30^{\prime}$ - $113^{\circ} 30^{\prime}$ BT dan $7^{\circ} 30^{\prime}$ $8^{\circ} 30^{\prime}$ LS. Wilayah ini meliputi 24 kecamatan; sisi utara dibatasi oleh Kabupaten Sidoarjo dan Selat Madura, sisi selatan oleh Kabupaten Malang, sisi timur dibatasi oleh Kabupaten Probolinggo, dan sisi barat oleh Kabupaten Mojokerto (Badan Pusat Statistik Kabupaten Pasuruan, 2019).

Tingkat kesejahteraan yang belum merata menyebabkan sejumlah masyarakat memilih kredit sebagai jalan keluar atas permasalahan ekonomi mereka. Dilansir oleh Situs Resmi Pemerintah Kabupaten Pasuruan (22/11/2019), calon debitur di Kabupaten Pasuruan mencapai 15.478 orang, namun realisasi pemanfaatan KUR masih sangat rendah yakni $15 \%$ dari total calon debitur. Hal itu disebabkan oleh minimnya pemahaman tentang manfaat KUR dan beberapa faktor lain. Beberapa faktor tersebut menjadi motivasi peneliti untuk menganalisis lebih lanjut mengenai fenomena kredit di lingkup Kabupaten Pasuruan, khususnya Kampung Kauman Kecamatan Pasrepan.

Pasrepan dikenal dengan lingkungannya yang agamis, dimana tidak kurang dari tujuh pondok pesantren berdiri di sana. Kampung Kauman di Desa Pasrepan yang menjadi fokus utama dalam penelitian ini memiliki sekitar 70\% masyarakat Kampung Kauman menggantungkan diri pada rentenir sebagai sumber keuangan mereka. Umumnya mata pencaharian masyarakat di Kampung Kauman memang tidak selalu menjamin sederetan kebutuhan sehari-hari; seperti pedagang kecil di pasar tradisional, pedagang kelontong, penjual gorengan, tukang pijat, pengrajin layangan, dan ibu rumah tangga. Dari total kurang lebih 30 kepala keluarga di Kampung Kauman, terdapat 21 kepala keluarga yang memiliki hutang pada rentenir.
Menjadi fenomena menarik ketika rentenir tumbuh subur di lingkungan yang seharusnya masyarakat lebih paham tentang haramnya riba, apalagi dengan tingkat bunga sangat tinggi. Parahnya lagi hutang yang diperoleh tidak hanya didapat dari satu orang rentenir, tetapi dua bahkan tiga rentenir. Jumlah uang yang terkumpul digunakan untuk "gali lubang tutup lubang". Hutang pertama yang belum dilunasi, mereka bayar dengan hutang dari rentenir lain, dan begitu seterusnya. Kredit yang mampu dilunasi menjadi syarat untuk memperoleh kredit periode berikutnya dengan jumlah lebih besar.

Dalam dunia konvensional, kredit dapat diperoleh melalui lembaga bank maupun pihak non formal, seperti rentenir atau yang biasa disebut lintah darat, ceti, dan tengkulak di desa-desa. Makna "rentenir" dalam Kamus Besar Bahasa Indonesia ialah orang yang mencari nafkah dengan membungakan uang; tukang riba; pelepas uang; lintah darat. Menurut Parlina (2017), kegiatan rentenir adalah suatu aktivitas yang memberikan pinjaman kepada orang yang membutuhkan dengan bentuk imbalan bunga sesuai ketentuan rentenir tersebut. Selain tingkat bunga yang sangat tinggi, kredit pada rentenir memiliki risiko lebih besar dibandingkan meminjam di bank. Kredit ini mampu melumpuhkan usaha yang seharusnya dapat meringankan modal, tetapi malah berdampak tekanan sosial apabila tidak bisa membayar kewajibannya. Biasanya debitur yang tidak mampu melunasi akan dipukuli dan bisa dipermalukan di depan umum.

Mekanisme memperoleh kredit pada rentenir sebenarnya tidak jauh dengan bank. Ketika syarat tertentu sudah terpenuhi dan kedua belah pihak melangsungkan transaksinya, maka uang atau dana yang diajukan akan cair dan bisa dimanfaatkan oleh debitur. Eksistensi rentenir di era perbankan modern kurang lebih sama dengan pedagang yang 
menjamur di pinggir jalan, meskipun tanpa izin, barang yang diperdagangkan seringkali lebih segar dan murah, serta memiliki pelayanan yang lebih cepat. Usaha mereka diperlukan, namun perlu diatur dan ditertibkan dalam peraturan perundangan supaya tidak rusuh dengan pembeli dan mengganggu lalu lintas. Penertiban dilakukan dengan gerakan moral dan prinsip hidup bermasyarakat yang baik sebagai tolok ukur dalam setiap hubungan hukum pinjammeminjam, termasuk ketika akan menjual barang jaminan. Perbuatan yang saling diharapkan, kapan dan di mana saja hukum kehidupan dinilai perlu diindahkan, termasuk rentenir (Sibarani, 2002).

Eksistensi rentenir yang tidak pernah padam menjadi pertanyaan besar, terutama atas tersedianya lembaga-lembaga kredit resmi yang tingkat bunganya relatif dan terkendali sesuai prime lending rate atau suku bunga dasar kredit oleh Bank Indonesia dan Otoritas Jasa Keuangan sebagai regulator dan pengawas kegiatan perbankan di Indonesia. Beberapa perbedaan antara rentenir dan lembaga perbankan modern ditunjukkan dalam Tabel 1.

\section{Tabel 1. Perbedaan antara Bank dan Rentenir}

\begin{tabular}{|c|c|c|}
\hline Klasifikasi & Bank & Rentenir \\
\hline Pengertian & $\begin{array}{l}\text { Bank adalah lembaga simpan pinjam } \\
\text { yang diawasi oleh Otoritas Jasa } \\
\text { Keuangan (OJK). }\end{array}$ & $\begin{array}{l}\text { Rentenir bukanlah lembaga atau } \\
\text { badan resmi. Rentenir ialah milik } \\
\text { personal dan bebas. }\end{array}$ \\
\hline Fungsi & $\begin{array}{l}\text { Fungsi bank sebagai pelayanan, kas } \\
\text { yang aman untuk menyimpan uang } \\
\text { dalam jumlah besar, serta sistem } \\
\text { pembayaran dengan jutaan jumlah } \\
\text { transaksi. }\end{array}$ & $\begin{array}{l}\text { Rentenir hanya dapat mengkreditkan } \\
\text { sejumlah uang. }\end{array}$ \\
\hline $\begin{array}{l}\text { Tingkat suku } \\
\text { bunga }\end{array}$ & $\begin{array}{l}\text { Bank tidak bebas menentukan tingkat } \\
\text { suku bunga. Terdapat prime lending rate } \\
\text { sebagai acuan. }\end{array}$ & $\begin{array}{l}\text { Rentenir menentukan tingkat suku } \\
\text { bunga sesuai keinginan mereka. }\end{array}$ \\
\hline $\begin{array}{l}\text { Posisi pada } \\
\text { suatu negara }\end{array}$ & $\begin{array}{l}\text { Sebagai penggerak roda ekonomi } \\
\text { negara, berfungsi sistematik. }\end{array}$ & $\begin{array}{l}\text { Tidak berfungsi sebagai penggerak } \\
\text { roda ekonomi negara secara } \\
\text { sitematik. }\end{array}$ \\
\hline Fasilitas & $\begin{array}{l}\text { Bank ialah penghubung, antara orang } \\
\text { kelebihan uang yang perlu tempat untuk } \\
\text { menyimpan, dan orang kekurangan uang } \\
\text { yang perlu dana untuk meminjam. }\end{array}$ & $\begin{array}{l}\text { Rentenir hanya menyangkut } \\
\text { pinjaman personal }\end{array}$ \\
\hline
\end{tabular}

Sumber: Abdurakhman, 2017 (diolah).

QS. Az-Zumar 39:18 menjelaskan bahwa manusia ialah makhuk sempurna yang Allah SWT ciptakan beserta akalnya supaya dapat menapaki kehidupan, membedakan sesuatu yang baik untuk dijalankan dan buruk untuk ditinggalkan. Oleh sebab itu, sudah menjadi kewajiban manusia untuk selalu berusaha dan memilah yang terbaik karena ia bermanfaat tanpa harus merugikan dirinya sendiri juga orang lain. Sesuai QS. Al-Maidah $5: 2$, berkembangnya zaman membuat tuntutan hidup manusia lebih kompleks dan berkembang, dan mendorong mereka untuk berupaya berbondong-bondong memenuhi kebutuhannya dengan berbagai cara mulai dari kebutuhan primer, sekunder, hingga tersier. Maka dari itu, manusia membutuhkan manusia lainnya sesuai kodratnya sebagai 
makhluk sosial, supaya tolong-menolong di dalam kebaikan, seperti jual beli, tukarmenukar, utang-piutang, sewa-menyewa, dan lain sebagainya. Hukum Islam tentang kewajiban dan hak dalam bermasyarakat disebut hukum mu'amalah. Mu'amalah ialah hubungan manusia yang saling berinteraksi dengan manusia lainnya yaitu sesuai syariat Islam. Selain dengan manusia, dituntut pula melaksanakan hubungan yang baik kepada Tuhannya (habl min Allah), dan wajib berperilaku baik dengan sesamanya (habl min an-nas).

Penelitian di India oleh Pandey et al. (2019) menemukan terdapat tingkat bunuh diri yang tinggi akibat dampak hutang yang tidak mampu dilunasi petani di Maharashtra. Sistem rentenir yang mudah dan cepat menjadi alasan utama mereka daripada harus meminjam di lembaga keuangan formal. Pertama-tama petani meminjam dari lembaga keuangan; ketika gagal membayar, mereka meminjam uang dari kreditur swasta dan dengan uang pinjaman tersebut mencoba membayar kembali sebagian dari pinjaman lama yang ada sebagai syarat siklus pinjaman berikutnya. Inilah yang menjadikan petani pada situs tersebut tidak kunjung lepas dari jeratan rentenir.

Hasil penelitian lainnya menunjukkan bahwa banyak orang bergantung pada rentenir karena proses dan persyaratan yang mudah dibanding dengan sumber pinjaman lain, serta efisiensi waktu dan energi. Demikian pula, sosialisasi pemberian pinjaman pemerintah salah satunya ialah melalui koperasi, tidak sepenuhnya dipahami dan diketahui oleh publik sehingga banyak orang terpaksa meminjam pada rentenir dengan sistem yang mereka sepakati (Siboro 2015). Penelitianpenelitian lain yang menunjukkan hasil sama, diantaranya adalah Balachandran \& Dhal (2018), Siboro (2015), Febrinasari et al. (2019), Khairi (2018), Suryono et al. (2015),
Rinda \& Aminda (2020), Jabeen (2019), serta Parlina (2017). Hassan \& Rashid (2018) dalam studinya menyatakan beberapa solusi yang diterapkan Bangladesh. Diantaranya ialah Kredit Mikro Islam, yaitu model peminjam sentris yang diusulkan dapat membantu mengurangi kemiskinan dan masalah rentenir internal melalui keterlibatan yang memadai dari pemangku kepentingan terkait.

Hasil studi tersebut berbeda dengan temuan Supramono \& Putlia (2010) bahwa hutang adalah stimulator oleh pemilik industri. Artinya, hutang bisa mendorong pemilik lebih profesional dan hati-hati dalam manajemen keuangan, lebih baik dalam bekerja, produktif dan disiplin, dipercaya orang lain, serta memiliki manfaat lebih besar daripada risiko. Selain itu, faktor psikologis dinilai sering menyebabkan bias dalam proses pengambilan keputusan keuangan termasuk kebijakan berhutang (Suryono et al., 2005; Nofsinger, 2005).

Begitu juga dengan Suryanto (2017) yang berargumen bahwa hutang merupakan hal yang positif sebagai sumber pendanaan serta dianggap sebagai stimulator dibanding beban. Terungkap pula bahwa faktor psychological bias terjadi di dalam pengambilan keputusan hutang. Ada tiga faktor psikologis yang dipandang dominan dalam pengambilan keputusan hutang pengusaha UMKM, yaitu optimist, availability, dan illusion of control.

Dari hasil telaah atas beberapa penelitian terdahulu, dan didukung fenomena pada Kampung Kauman Desa Pasrepan Kabupaten Pasuruan yang memiliki lingkungan agamis namun tingkat kredit rentenir sangat tinggi, maka peneliti tertarik untuk melakukan analisis dengan fokus penelitian pada makna hutang menurut masyarakat Kampung Kauman yang lebih memilih rentenir dibandingkan bank sebagai sumber kredit usaha mereka. 


\section{Memahami Kredit}

Kredit berasal dari bahasa Latin credo yang berarti "saya percaya", ialah kombinasi dari bahasa Sanskerta cred yang artinya "kepercayaan", dan bahasa Latin do berarti "saya tempatkan". Ketika seseorang memilih kredit, artinya ia memperoleh kepercayaan, maka atas dasar kepercayaan pada seseorang yang memerlukannya diberikan uang, barang atau jasa dengan syarat mengembalikannya dalam jangka yang telah disepakati (Hariyani, 2010; Untung, 2005). Sedangkan pengertian kredit pada pasal 1(11) UU No. 10/1998 perubahan atas UU No. 1992 tentang perbankan, ialah penyediaan uang atau tagihan yang dapat dipersamakan dengan itu, berdasarkan persetujuan atau kesepakatan pinjam-meminjam antara bank dengan pihak lain yang mewajibkan pihak peminjam untuk melunasi hutangnya setelah jangka waktu tertentu dengan pemberian bunga.

Kredit adalah semua jenis pinjaman yang harus dibayar beserta bunganya oleh peminjam dengan perjanjian yang sudah disepakati (Hasibuan, 2009). Kredit juga diartikaan sebagai penyerahan barang, jasa atau uang dari satu pihak (pemberi pinjaman atau kreditur) atas dasar kepercayaan kepada pihak lain (penghutang/borrower ataupun nasabah) dengan perjanjian pembayaran kredit dilakukan pada waktu yang kedua belah pihak telah sepakati (Rivai et al., 2014). Kredit juga merupakan sesuatu yang dibayar secara berangsur-angsur baik dalam pinjammeminjam maupun jual beli (Suhendi, 2005).

Beberapa unsur kredit ialah mengenai kepercayaan, waktu, tingkat risiko (degree of risk), penyerahan, dan perjanjian atau persetujuan. Dalam ekonomi Islam, kredit dengan instrumen utamanya ialah bunga, hukumnya haram. Bunga sama dengan riba, riba menurut bahasa berarti tambahan (az-ziyadah), berkembang (an-numuw), meningkat (al-irtifa'), dan membesar (al-'uluw). Maka riba adalah penambahan, perkembangan, peningkatan, dan pembesaran atas pinjaman pokok yang diterima kreditur sebagai imbalan karena telah menangguhkan sebagian modalnya selama periode tertentu (Hassan \& Rashid, 2018; Ramadhan, 2018).

Riba secara garis besar dibagi menjadi dua, yaitu riba jual beli dan riba tentang piutang. Riba jual beli dibagi menjadi dua macam, yaitu riba fadhl dan riba nasi'ah. Sedangkan riba hutang piutang dibedakan menjadi dua macam, yaitu riba qardh dan riba jahiliyah. Riba tidak hanya berdampak negatif pada ekonomi, tetapi juga aspek sosial masyarakat. Maka karena itu Islam menghalalkan jual beli namun mengharamkan riba (QS. Al-Baqarah 2:275). Terdapat tiga karakteristik mendasar yang dinilai terdapat dalam riba, yaitu: (1) Sifat riba yang berlipat ganda; (2) Sifat riba yang menganiaya mitra bisnis; serta, (3) Melumpuhkan dunia bisnis, menggerakkan sektor riil, dimana ini disebabkan bagi pihak yang memiliki dana lebih baik meminjamkan uangnya dibandingkan harus berpikir dan bekerja keras (Sula, 2004).

\section{Rentenir}

Rentenir berasal dari bahasa Belanda rentenier, dalam Kamus Internasional (Osman Raliby); rentenir berarti "pemakan riba atau bunga uang”. Agama apapun mengharamkan, mengecam dan mengancam pemakan riba. Riba mengoyak dan memusnahkan semangat tolong-menolong yang seharusnya melandasi peradaban umat manusia sebagai makhluk sosial (Nasar, 2018). Hukum syariat pun melarang segala tindakan memeras sesama manusia dengan menggunakan uang maupun barang ataupun jasa lainnya.

Beberapa perbandingan antara bank dan rentenir dinyatakan sebagai berikut (Siahaan, 2015). Pertama, bunga yang diberikan rentenir sebesar $20 \%$ per bulan bahkan lebih, sedangkan bunga bank pemerintahan rata-rata 
sebesar $2 \%$ per bulan. Kedua, rentenir tanpa agunan sedangkan bank pemerintah dengan agunan, dan biasanya agunan ini sulit dipenuhi karena jika memiliki agunan lebih baik dijual untuk modal usaha. Ketiga, rentenir sangat mudah meminjamkan uang, yang hanya disebut "butuh uang" maka akses langsung diberikan, sedangkan pada bank pemerintah memiliki sistem yang berlaku. Keempat, pada rentenir apabila tidak membayar maka langsung dieksekusi sendiri dengan mengambil perabot rumah yang kesannya kejam, sedangkan bank pemerintah menjual agunan untuk melunasi kredit dan kelebihannya dikembalikan kepada debitur. Kelima, rentenir jika terlambat membayar angsuran dikenakan denda, demikian juga bank pemerintah yang disebut bungaberbunga; namun demikian, jumlah yang dibayarkan pada rentenir bisa mencapai dua bahkan berkali-kali lipat.

Beberapa karakteristik lain dari sistem rentenir yang tak dimiliki lembaga keuangan formal menurut Arief et al. (2013) adalah seperti berikut. Pertama, tidak ada minimal dan maksimal peminjaman dana pada sistem rentenir. Kedua, dana pinjaman pada sistem rentenir bisa dicairkan dengan cepat, sewaktuwaktu dan dalam keadaan bagaimanapun, tanpa harus menempuh prosedur yang rumit. Ketiga, peminjaman pada sistem rentenir sangat efektif, bersifat terbuka, dan sederhana tanpa melalui peng-isian formulir dan syaratsyarat yang ribet. Keempat, sistem rentenir tidak menggunakan agunan atau jaminan karena rasa saling percaya. Kelima, sistem rentenir menggunakan biaya transaksi yang rendah bahkan tidak ada biaya transaksi. Keenam, dana rentenir tidak hanya untuk kebutuhan modal perekonomian, tetapi juga untuk hal-hal yang mendesak, seperti biaya berobat, pendidikan, dan lain-lain. Ketujuh, tidak hanya diakses oleh anggota, tetapi sistem rentenir untuk semua kalangan.

\section{Bias Psikologis}

Faktor psikologis sering menyebabkan bias dalam pengambilan keputusan keuangan termasuk hutang (Supramono \& Putlia, 2010; Nofsinger, 2005). Hal ini dikarenakan faktor psikologis cenderung menimbulkan bentuk keputusan bersifat subyektif atau berdasarkan emosi dan bukan karena berbasis logika dari pengambil keputusan

Terdapat 13 faktor psikologis yang berperan dalam pengambilan keputusan finansial, yaitu bias, excessive optimism, overconfidence, confirmation bias, illusion of control, heuristic, representativeness, availability, anchoring and adjustment, affect, framming effect, loss aversion, aversion to a sure loss (Sarimatua \& Husaini, 2017).

\section{Perilaku Keuangan}

Perilaku keuangan menjadi tolok ukur seorang individu ketika dihadapkan dengan pilihan dalam keputusan keuangan. Perilaku keuangan juga bisa dimaknai sebagai suatu teori yang didasarkan atas ilmu psikologi tentang bagaimana penyimpanan kognitif dan emosi dapat mempengaruhi perilaku pelaku ekonomi.

Dalam arus perekonomian global saat ini, setiap individu harus melek finansial, mengarah pada perilaku keuangan yang sehat sehingga dapat mengelola keuangannya dengan baik. Kendali diri adalah perilaku keuangan yang sangat penting dan bermanfaat jika bisa diterapkan di kehidupan sehari-hari (Lubis et al., 2013).

\section{Agamis}

Agama, berasal dari bahasa Sanskerta yaitu ăgama (baca: aagama) yang berarti "tradisi". Agamis kata dasarnya adalah agama. Agama yang mendapat akhiran is yang menunjukkan sifat, dengan vokal akhiran a pada kata dasar dihilangkan. Akhiran is di-ambil dari bahasa Belanda dan 
Inggris, menunjukkan orang yang melakukan kata kerja yang terkait. Agama ialah permanen, yaitu petunjuk kehidupan yang bersumber dari Zat Maha Pencipta. Agama menjadi landasan makna pada kehidupan.

Makna yang tersimpul dalam agama menjelaskan tentang tujuan mengapa manusia diciptakan, apa yang harus dikerjakan oleh manusia agar sesuai dengan tujuan penciptaan tersebut. Setiap perbuatan manusia dibebani tanggung jawab (mas-uliah), dan agama menjelaskan pertanggungjawaban melalui keputusan Yang Maha Adil di akhirat (Lubis, 2017). Tolok ukur dari agama adalah benarsalah, baik-buruk, serta manfaat-merugikan. Menurut Kuntowijoyo, agama dapat dimanifestasikan ke dalam berbagai bidang termasuk ekonomi (Ramadhan, 2018). Agamis atau agama menurut Mangunwijaya (1982) lebih menunjuk tentang kelembagaan, kebaktian kepada Tuhan atau dunia atas aspek resminya, yuridis, peraturan dan sebagainya, meliputi segi-segi kemasyarakatan.

\section{METODE PENELITIAN}

Penelitian ini menggunakan pendekatan kualitatif, dimana peneliti sebagai instrumen kunci (Sugiyono, 2018; Fuad et al., 2018). Teknik pengumpulan data melalui observasi, wawancara, dan dokumentasi. Analisis data bersifat induktif/kualitatif. Jenis penelitian yang digunakan peneliti adalah studi kasus. Data primer diperoleh melalui wawancara sedangkan data sekunder berupa rincian sistem kredit pada rentenir.

Metode analisis data penelitian ini menggunakan model Miles dan Huberman, yang mencakup tiga aktivitas analisis, yaitu data reduction, data display, dan conclusion drawing atau verification (Sugiyono, 2018; Fuad et al., 2018).

Aktivitas pertama adalah data reduction (reduksi data). Mereduksi data berarti merangkum, memilih hal-hal yang pokok, memfokuskan pada hal-hal yang penting, dicari tema dan polanya. Dengan demikian, data yang telah direduksi akan memberikan gambaran yang lebih jelas dan mempermudah peneliti untuk melakukan pengumpulan data selanjutnya, dan mencarinya bila diperlukan.

Dalam mereduksi data, setiap peneliti akan dipandu oleh tujuan yang akan dicapai. Tujuan utama penelitian kualitatif adalah pada temuan, oleh karena itu jika peneliti menemukan segala sesuatu yang asing, tidak dikenal, belum memiliki pola (Sugiyono, 2018). Justru itulah yang harus dijadikan perhatian dalam melakukan reduksi data. Ibarat melakukan penelitian di hutan, maka pepohonan, tumbuhan serta binatang yang belum dikenal selama ini akan dijadikan fokus untuk penelitian selanjutnya. Reduksi data merupakan proses berpikir sensitif yang membutuhkan kecerdasan dan keluasan wawasan yang tinggi.

Aktivitas berikutnya adalah data display (penyajian data). Dalam penelitian kualitatif, penyajian data dilakukan dalam bentuk uraian singkat, bagan, hubungan antar kategori, flowchart dan sejenisnya. Miles dan Huberman (1984 dalam Sugiyono, 2018) menyatakan bahwa "the most frequent from of display data for qualitative research data in the past has been narrative text". Artinya bahwa yang paling sering digunakan untuk menyajikan data dalam penelitian kualitatif adalah dengan teks yang bersifat naratif.

Aktivitas terakhir yaitu conclusion drawing atau verification, atau aktivitas penarikan kesimpulan ataupun verifikasi. Kesimpulan awal yang dikemukakan sebelum nya masih bersifat sementara, dan akan berubah bila tidak ditemukan bukti-bukti kuat yang mendukung pada tahap pengumpulan data berikutnya. Namun demikian, apabila kesimpulan yang dikemukakan pada tahap awal didukung oleh bukti-bukti yang valid dan konsisten yang diperoleh saat peneliti 
kembali ke lapangan mengumpulkan data, maka kesimpulan yang dikemukakan merupakan kesimpulan yang kredibel.

Kesimpulan dalam penelitian kualitatif merupakan temuan baru, yang sebelumnya belum pernah ada. Dengan demikian, kesimpulan di dalam penelitian kualitatif mungkin dapat menjawab rumusan masalah yang dirumuskan sejak awal, tetapi mungkin juga tidak. Hal ini karena seperti telah dikemukakan bahwa masalah dan rumusan masalah dalam penelitian kualitatif masih bersifat sementara dan akan berkembang setelah penelitian berada di lapangan.

Proses penelitian di Kampung Kauman dilakukan sebanyak tiga kali, dengan profil informan dideskripsikan dalam Tabel 2.

\section{HASIL ANALISIS}

\section{Hasil Penelitian}

Hasil wawancara dengan para informan mengenai sistem kredit dari rentenir pada situs penelitian Kampung Kauman secara umum bisa diperinci sebagai berikut. Setiap kelipatan kredit sebesar Rp. 2.000.000,warga yang berhutang membayar 50 kali cicilan sebesar Rp. 50.000,- per minggu selama setahun. Jika nilai pembayaran itu dijumlahkan maka warga secara total harus mengembalikan dana kredit tersebut sebesar Rp. 2.400.000,-. Dengan demikian, untuk setiap kelipatan nominal kredit tersebut memiliki tingkat bunga sebesar $20 \%$, yaitu sebesar Rp. 400.000,-

Tabel 2. Profil Informan

\begin{tabular}{clll}
\hline No & \multicolumn{1}{c}{ Nama } & Umur & \multicolumn{1}{c}{ Pekerjaan } \\
\hline 1 & Ibu Nafila & 42 tahun & Memiliki warung kopi \\
2 & Ibu Siti Ulfa & 33 tahun & Pedagang bakso \\
3 & Ibu Romdona & 48 tahun & Konter HP \\
4 & Ibu Ernawati & 40 tahun & Memiliki toko kelontong \\
5 & Ibu Sapanah & 50 tahun & Tukang pijet \\
6 & Ibu Nafisa & 43 tahun & Pedagang makanan ringan \\
7 & Ibu Sawiah & 48 tahun & Pedagang bumbu di pasar \\
8 & Ibu Bawon & 38 tahun & Pedagang online \\
9 & Ibu Inayah & 50 tahun & Memiliki toko kelontong \\
10 & Ibu Hafidatul & 22 tahun & Pedagang lele \\
11 & Ibu Hilyatun & 36 tahun & Konter HP \\
12 & Ibu Ismi & 20 tahun & Ibu rumah tangga \\
13 & Ibu Khodijah & 47 tahun & Pedagang bumbu di pasar \\
14 & Ibu Siyami & 45 tahun & Memiliki toko di pasar \\
15 & Ibu Sholihati & 54 tahun & Memiliki warung nasi \\
16 & Ibu Husnawati & 38 tahun & Ibu rumah tangga \\
17 & Ibu Sofeyah & 31 tahun & Pengrajin layangan \\
18 & Ibu Hafiyah & 35 tahun & Pedagang gorengan \\
19 & Ibu Husnul & 38 tahun & Ibu rumah tangga \\
20 & Ibu Khodijah & 40 tahun & Pembuat kue \\
21 & Ibu Robi'atul & 35 tahun & Memiliki warung nasi \\
\hline
\end{tabular}

Sumber: Data Primer (diolah), 2019 
Tabel 3. Makna Hutang menurut Informan

\begin{tabular}{|c|c|c|c|}
\hline No & Nama & Pernyataan & Tema \\
\hline 1 & Ismi & $\begin{array}{l}\text { Kalau sewaktu-waktu butuh modal atau } \\
\text { kebutuhan lain yang mendesak, pasti cairnya } \\
\text { tidak ribet. Kadang untuk modal dulu, } \\
\text { kadang bisa langsung konsumsi. }\end{array}$ & \\
\hline 2 & Siti Ulfa & $\begin{array}{l}\text { Modal usaha sebagian dari rentenir ini. } \\
\text { Kalau mau pinjam ke bank bakal panjang } \\
\text { urusannya, belum tentu cair. }\end{array}$ & $\begin{array}{l}\text { Modal usaha yang dapat } \\
\text { diperoleh secara cepat }\end{array}$ \\
\hline 3 & Bawon & $\begin{array}{l}\text { Sebagian dipakai untuk modal, sebagian juga } \\
\text { langsung dibelanjakan, nanti uangnya bakal } \\
\text { berputar, Ibu gunakan untuk menutup lagi. }\end{array}$ & \\
\hline 4 & Hafiyah & $\begin{array}{l}\text { Ibu-ibu kalau bareng-bareng (bersama- } \\
\text { sama) seperti itu sayuk (rukun), karena akan } \\
\text { jarang kalau sudah sibuk cari sandang } \\
\text { pangan (bekerja) sendiri-sendiri. } \\
\text { Alhamdulillah di samping untuk tambahan } \\
\text { uang harian, akan berputar untuk kebutuhan } \\
\text { yang lain. }\end{array}$ & \\
\hline 5 & Husnul & $\begin{array}{l}\text { Cukup di rumah, waktunya kumpul tarikan } \\
\text { hadir, ketemu teman-teman yang lain, } \\
\text { sambung dulur (menyambung persaudaraan), } \\
\text { seperti itulah urip (hidup) dengan tetangga. }\end{array}$ & \\
\hline 6 & Hilyatun & $\begin{array}{l}\text { Bisa kumpul dengan tetangga, yang jarang } \\
\text { bisa ngobrol jadi ketemu. Nambah rukun, } \\
\text { nambah kompak. }\end{array}$ & \\
\hline 7 & Nafisa & $\begin{array}{l}\text { Jadi bisa ngumpul dengan tetangga, Ibu-ibu } \\
\text { juga saling meringankan kalau ada kredit } \\
\text { tersebut, ketika tetangganya memang benar- } \\
\text { benar tidak ada uang untuk membayar } \\
\text { penarikan, harus ada yang legowo (berlapang } \\
\text { dada) meminjami dulu. }\end{array}$ & Wadah silaturahmi \\
\hline 8 & Robi'atul & $\begin{array}{l}\text { Kumpul-kumpul, dengan tetangga rukun, } \\
\text { yang biasanya jarang ketemu bisa ketemu } \\
\text { kabar-kabar, semua orang punya kesibukan } \\
\text { beda-beda, ada yang ke sawah ada yang ke } \\
\text { pasar, kalau tidak seperti itu akan jarang } \\
\text { duduk bareng. }\end{array}$ & \\
\hline 9 & Sholihati & $\begin{array}{l}\text { Senang kumpul-kumpul dengan tetangga, } \\
\text { karena belum tentu bisa lengkap, kelihatan } \\
\text { rukun, kalau ada kurang bisa dijunjung } \\
\text { bareng (dijinjing bersama). }\end{array}$ & \\
\hline 10 & Sofeyah & $\begin{array}{l}\text { Rembug (berkumpul) dengan tetangga, kalau } \\
\text { tidak seperti itu akan jarang, mungkin hanya } \\
\text { sak klebat-klebat (sekilas-sekilas), bisa } \\
\text { jagongan (ngobrol) kabar-kabar, hilang } \\
\text { jenuh juga }\end{array}$ & \\
\hline
\end{tabular}




\begin{tabular}{ll}
\hline 1 Nafila & $\begin{array}{l}\text { Dari kredit ini ibu-ibu di Kampung Kauman } \\
\text { jadi sering ngumpul, gotong royong, nambah } \\
\text { kerukunan. }\end{array}$
\end{tabular}

12 Romdona

Alhamdulillah dengan tetangga, siapa yang ada uang bisa nutup kekurangannya (kredit), sementara dibantu, kalau sudah ada pasti dikembalikan.

13 Khodijah

14 Inayah

15 Husnawati

16 Ernawati

18 Sawiah

19 Sapanah

20 Hafidatul

Sebenarnya seperti ini saling membantu, kadang ada yang belum punya uang untuk cicilan, yang sudah punya bisa meminjami asalkan jangan banyak-banyak, karena kadang juga sama-sama minim, pokok siapa yang sekiranya longgar.

Selain untuk modal, gotong royong dengan tetangga, kalau kita hadir tarikan berarti sudah membantu, kalau terpaksa belum bisa nyicil, siapa yang longgar bisa nggajuli (menggantikan sementara), begitulah hidup di kampung.

Karena jaminannya diri sendiri, jadi kelompoknya harus kompak. Siapa-siapa yang bisa membantu membayar cicilan anggota lain terlebih dahulu, karena mendesak tidak bisa hadir, kalau sewaktu-waktu tidak bisa hadir juga bisa dibantu yang lain.

Kalau pas kumpulan ada yang belum bisa nyukupi (mencukupi), nanti ditalangi (dipinjami) dulu, minggu depan pasti diganti. Nah makanya kalau memang benar-benar belum bisa pulang karena dagangan di toko, ada yang minjami dulu, saling bergantian, kalau tidak begitu kelompoknya eman-eman (disayangkan).

17 Siyami Sudah dibantu, sama-sama membantu, samasama bekerja, kalau ada lebihnya mboten nopo-nopo (tidak apa-apa), kalau tidak begitu mereka dapat untung dari mana.

Mungkin tidak apa-apa, soalnya sama-sama ada kebutuhan, ada plus minus, dipinjami uang, yang lain itu keuntungan mereka.

Kebutuhan kami yang harus dicukupi, sedangkan mereka juga mencari keuntungan untuk hidup, yang penting sama-sama rela.

Kalau tidak ada tambahan pada kredit tersebut, mereka akan dapat untung dari mana, mereka juga harus memenuhi kebutuhan hidup. Kami juga sudah ditolong, dipinjami uang, jadi saling menolong.
Adanya gotong royong, saling tolong menolong

$$
\begin{aligned}
& \text { Bunga kredit oleh warga } \\
& \text { dianggap sebagai balas jasa } \\
& \text { kepada rentenir }
\end{aligned}
$$


21 Khodijah Namanya juga ditolong, kalau sudah dibantu maka diberi upah, nah upahnya dari bunga itu, sama-sama mencari makan.

Sumber: Data Primer (diolah), 2019

Hasil transkripsi wawancara mengenai makna hutang bagi para informan yang merupakan anggota kredit rentenir di Kampung Kauman Desa Pasrepan Kabupaten Pasuruan bisa dirangkum seperti terlihat dalam Tabel 3.

Tema pertama yang diperoleh adalah bahwa kredit rentenir adalah "modal usaha yang dapat diperoleh secara cepat". Hal ini karena mata pencaharian yang tidak selalu tentu mencukupi kebutuhan hidup dari masyarakat Kampung Kauman, sehingga membuat kredit rentenir sebagai salah satu pilihan sumber modal mereka. Terdapat tiga orang informan yang memaknai hutang dari rentenir sebagai modal usaha yang dapat diperoleh secara cepat, yaitu Ibu Ismi, Siti Ulfa, dan Bawon.

Tema kedua yang diperoleh bahwa kredit rentenir dimaknai sebagai "wadah silaturahmi”. Kredit yang dilakukan oleh masyarakat Kampung Kauman Desa Pasrepan Kabupaten Pasuruan tidak hanya karena motif ekonomi, tetapi bias psikologis dinilai turut menjadi faktor keputusan keuangan mereka. Jadwal penarikan cicilan kredit oleh rentenir menjadi wadah untuk bersilaturahmi dengan tetangga sekitar. Hal tersebut dirasa dapat mempererat kebersamaan dan kerukunan antar sesama. Pernyataan ini bisa dinilai irasional, dan bertolak belakang dengan makna hutang yang sering dianggap negatif karena perekonomian seseorang belum mandiri dan minus. Mayoritas informan, yaitu tujuh orang dari total 21 orang, memaknai kredit rentenir ini sebagai wadah silaturahmi adalah Ibu Hafiyah, Husnul, Hilyatun, Nafisa, Robi'atul, Sholihati, dan Sofeyah.

Tema ketiga yang diperoleh dari para informan bahwa kredit rentenir dimaknai mengandung "adanya gotong royong, saling tolong menolong”. Kredit oleh rentenir diadakan dengan pola setiap satu kampung terdapat satu kelompok kredit yang terdiri dari ibu-ibu. Jadi ketika salah satu anggota kredit tidak dapat hadir dan mencicil angsuran, maka semua anggota kelompok wajib menopang untuk cicilannya. Jika tidak demikian, maka akan berdampak pada kredit periode selanjutnya. Enam orang berpendapat bahwa dengan adanya rentenir maka mereka bisa saling meringankan antar anggotanya, bergotong royong dan bersikap saling tolong menolong. Para informan yang menyatakan tema ketiga ini ialah Ibu Nafila, Romdona, Khodijah, Inayah, Husnawati, dan Ernawati.

Tema terakhir yang diperoleh bahwa kredit rentenir dimaknai bahwa "bunga kredit oleh warga dianggap sebagai balas jasa kepada rentenir". Menurut lima orang anggota kredit yang merupakan informan penelitian ini, hukum yang berkenaan dengan bunga kredit pada rentenir dianggap sebagai balas jasa atas bantuan yang telah rentenir berikan. Para informan yang menyatakan tema ini yaitu Ibu Siyami, Sawiah, Sapanah, Hafidatul, dan Khodijah. Mengenai riba dalam kredit, masyarakat tidak terlalu menganggapnya sebuah masalah. Mereka ikhlas untuk nominal tambahan, sebagai tanda terimakasih dan balas jasa atas pinjaman yang rentenir berikan untuk kebutuhan sehari-hari.

\section{Pembahasan}

Berdasarkan hasil wawancara dengan 21 informan, dan mengaitkan hasil tersebut kepada sejumlah teori dan temuan penelitian terdahulu, maka dinyatakan terdapat beberapa faktor yang mendukung masyarakat Kampung 
Kauman untuk lebih memilih rentenir sebagai sumber permodalan daripada memperoleh kredit melalui lembaga bank.

Faktor pertama adalah untuk memenuhi kebutuhan hidup. Faktor pertama ini muncul berdasarkan sebagian besar pernyataan dari informan, bahwa: "Penghasilan suami tidak tentu. Kalau tidak pinjam ke rentenir, tidak cukup untuk kebutuhan sehari-hari. Uang yang diperoleh bisa untuk modal juga." Faktor ini sesuai dengan hierarki kebutuhan (hierarchy of needs) milik Abraham Maslow menyatakan setiap diri manusia memiliki hierarki kebutuhan, dimana beberapa jenis kebutuhan lebih diutamakan dibandingkan dengan kebutuhan yang lain (Robbins \& Judge, 2008).

Faktor kedua adalah syarat yang mudah untuk memperoleh kredit dari rentenir, yaitu hanya berupa foto copy $\mathrm{KK}$, KTP, dan surat pernyataan beserta tanda tangan kepala keluarga ataupun yang mewakili. Rentenir dianggap memiliki sistem dengan syarat yang lebih mudah, prosedur, serta perolehan akses kredit yang sering dilakukan dengan door to door. Pernyataan dari informan terkait faktor ini adalah: "Syaratnya mudah, tidak ribet pergi ke kelurahan ataupun kecamatan untuk mencari surat-surat keterangan, apalagi pas mendesak, belum tentu syarat yang diperlukan sudah jadi, nunggu lagi antri lama." Dampaknya, masyarakat yang masih menganggap pengajuan kredit di bank rumit dengan syarat, jaminan, maupun prosedur administrasi, akhirnya lebih memilih rentenir sebagai sumber kreditnya. Ditambah lagi asumsi bahwa yang bisa meminjam di bank hanyalah mereka yang memiliki transaksi dan saldo sangat tinggi, seperti manajer dan direktur, untuk memperoleh kredit perbankan.

Faktor berikutnya adalah fakta bahwa nasabah tidak perlu datang jauh-jauh ke bank, melainkan rentenir datang menghampiri ke rumah-rumah warga. Kondisi ini sesuai keterangan dari seorang informan: "Kredit di rentenir gampang, tidak perlu jauh-jauh ke bank. Mereka rutin setiap penarikan datang ke salah satu rumah anggota kredit, sudah terjadwal bersama-sama dengan ibu-ibu yang lain." Seperti juga diargumentasikan oleh Danusaputro et al. (1997), bahwa rentenir tidak hanya memberi kemudahan pada prosedur, akad maupun administrasi saja, akan tetapi semua dibuat mudah olehnya. Bahkan untuk dana yang dipinjam, mereka mengantarkan uang itu sendiri, termasuk datang kembali guna menerima angsuran pinjamannya kepada masyarakat di desa-desa.

Faktor keempat adalah tidak adanya jaminan. Jaminan (collateral) adalah penyerahan kekayaan atau pernyataan kesanggupan seseorang untuk menanggung pembayaran kembali suatu hutang (Rahmatullah, 2015; Untung, 2005). Pernyataan dari informan terkait faktor ini adalah: "Agunan yang diperlukan hanya kehadiran masing-masing, diri kita sendiri. Kalau hadir berarti absen hitam, kalau titip saja itu dianggap tidak hadir, jadi absennya merah." Dengan demikian, dalam sistem kredit rentenir, jaminannya ialah diri nasabah sendiri saat jadwal kumpulan penarikan cicilan kredit. Jika absen kedatangan mereka baik maka akan berdampak pada nilai kredit yang akan diperoleh di periode berikutnya.

Faktor kelima adalah dana kredit rentenir yang dibutuhkan dapat cair dengan cepat tanpa prosedur yang panjang dan ribet. Seperti pernyataan dari seorang informan terkait proses memperoleh kredit rentenir, yaitu: "Prosesnya tidak rumit, jadi kreditnya cair dengan cepat, tidak harus riwa-riwi (mondar-mandir), mboten repot (tidak repot)." Sama halnya bank, pencairan kredit oleh nasabah akan tercapai jika syarat-syarat yang harus dipenuhi nasabah telah dilaksanakan (Suyatno et al., 2007; Sudarsono, 2003). Namun dibandingkan kredit perbankan, kredit 
kepada rentenir ini memiliki syarat yang jauh lebih sederhana. Fakta ini diperkuat oleh pernyataan Siahaan (2015), bahwa rentenir dekat sekali dengan nasabah dan hadir setiap saat kepada warga yang butuh dana cepat.

Faktor terakhir adalah cicilan kredit yang ringan Meskipun bunga kredit pada rentenir jauh lebih tinggi dibandingkan bank, namun cicilan dapat diangsur sedikit demi sedikit. Sesuai pernyataan informan bahwa: "Kalau di rentenir bisa dicicil per minggu kreditnya, tidak terasa tiba-tiba sudah lunas. Meskipun pernah dihitung sebenarnya besar juga bunganya, tapi mampunya seperti itu. Di bank lebih tidak kuat lagi, sekali mengembalikan harus seluruh dari total hutang, lebih sulit sepertinya." Dengan demikian, walaupun menyadari fakta bahwa total pengembalian untuk kredit rentenir adalah jauh lebih besar dibandingkan bila meminjam di perbankan, tetapi warga masih merasa kredit dari rentenir lebih ringan dalam proses cicilannya.

Dugaan tentang agamis dalam diri seseorang tidak menjamin atas keputusan hutang yang dasarnya ialah riba, meskipun tempat tinggal mereka di daerah pondok pesantren. Bunga atau riba yang terkandung dalam kredit pada rentenir bukanlah sebuah kendala menurut masyarakat Kampung Kauman. Kelebihan dari pengembalian kredit tersebut, mereka anggap sebagai tanda terima kasih serta balas jasa atas bantuan yang diberikan rentenir.

Makna "agamis" adalah berbeda dengan "religius", tetapi keduanya tidak bisa dipisahkan karena saling berkaitan. Hal tersebut sesuai dengan pernyataan dari Mangunwijaya (1982), bahwa agamis atau agama lebih menunjuk tentang kelembagaan, kebaktian kepada Tuhan atau dunia atas aspek resminya, yuridis, peraturan-peraturan dan sebagainya, serta meliputi segi-segi kemasyarakatan. Sedangkan religius lebih tentang aspek-aspek yang telah dihayati seseorang dalam hati, sikap personal seseorang yang mencakup totalitas pada pribadi manusia.

Dengan mengaitkan antara pemaknaan hutang rentenir menurut para informan dengan faktor-faktor yang dinilai mendukung masyarakat Kampung Kauman Desa Pasrepan lebih memilih rentenir sebagai lembaga penyedia uang sebagai modal usaha dibandingkan lembaga perbankan, maka proposisi yang dimunculkan pada penelitian ini adalah: "Kredit pada rentenir bisa bermakna sebagai wadah silaturahmi bagi warga masyarakat". Proposisi ini muncul dikarenakan mayoritas informan penelitian menyatakan bahwa selain mendapat pinjaman sejumlah uang, mereka bisa berkumpul bersama menyambung silaturahmi yang mana kondisi ini sering terhalang akibat kesibukan dari pekerjaan masing-masing. Selain itu, unsur gotong-royong dan saling tolong menolong yag dirasakan para informan juga menambah kebersamaan mereka.

\section{SIMPULAN}

Hasil penelitian ini menemukan adanya beberapa makna 'kredit pada rentenir' yang dimiliki dalam persepsi warga Kampung Kauman Desa Pasrepan, yaitu: (1) sebagai modal usaha yang dapat diperoleh secara cepat; (2) wadah silaturahmi; (3) adanya gotong royong, saling tolong menolong; serta, (4) bunga kredit oleh warga dianggap sebagai balas jasa kepada rentenir.

Secara teoritis, penelitian ini mampu mengeksplorasi pemahaman yang dimiliki masyarakat Kampung Kauman bahwa kredit melalui rentenir yang kemudian bisa dinilai memiliki banyak ketidakefektifan meskipun dirasa lebih ringan. Selain itu juga, informasi tentang kredit di lembaga bank tidak serumit seperti yang mereka bayangkan, serta manajemen keuangan yang baik, akan memudahkan warga untuk tidak besar pasak daripada tiang. Upaya tersebut tidak lepas dari 
tangan pemerintah terkait. Sosialisasi dan pendisiplinan rentenir yang kerap merugikan masyarakat, diharapkan lebih tegas sehingga tidak ada lagi kredit rentenir yang terus menjerat warganya.

Penelitian dengan para informan, dan lokasi penelitian hanya di wilayah Kampung Kauman, dinilai merupakan kelemahan utama dari penelitian ini. Karenanya disarankan agar bagi para peneliti selanjutnya untuk memperbanyak informan agar data yang dihasilkan lebih akurat. Selain itu, dapat memperluas lokasi penelitian, sehingga bisa diperoleh perbandingan hasil penelitian. Izin kepada pihak yang terlibat sangat diharuskan, agar dalam proses penelitian tidak terjadi kesalah pahaman karena isu ini cukup sensitif bagi masyarakat terkait.

\section{REFERENSI}

Abdurakhman, H. (2017). Islam untuk Indonesia: Tantangan dan harapan. Nuansa Cendekia.

Arief, Zainol, M., \& Sutrisni. (2013). Praktek rentenir penghambat terwujudnya sistem hukum perbankan syariah di Kabupaten Sumenep. PERFORMANCE: Jurnal Bisnis \& Akuntansi, 3(2), 63-82. Retrieved from https://ejournalwiraraja. com/index.php/FEB/issue/view/3.

Badan Pusat Statistik Kabupaten Pasuruan. (2019). Kabupaten Pasuruan dalam angka. Retrieved from www.pasuruan kab.bpps.go.id.

Balachandran, R. P. \& Dhal, S. C. (2018). Relationship between money lenders and farmers: Theoretical perspective and evidence from potato farmers of West Bengal, India. Agricultural Finance Review, 78(3), 330-347. doi: 10.1108/ AFR-07-2016-0066.

Danusaputro, M., Colter, J. M., \& Suharto, P. (1997). Monetisasi pedesaan: Bunga rampai keuangan pedesaan. Institut Bankir Indonesia.
Febrinasari, Suryaningsih \& Syafitri, R. (2019). Tindakan masyarakat melakukan pinjaman dana pada rentenir di Kampung Sembuang Desa Penuba Timur Kecamatan Selayar Kabupaten Lingga. Skripsi. Universitas Maritim Raja Ali Haji.

Fuad, M., Sudarma, M., \& Irianto, G. (2019). Exploration of obstacles faced by successors in the intergenerational transition process of family business. Journal of Applied Management (JAM), 17(1), 20-29. doi: 10.21776/ub.jam. 2019.017.01.03.

Hariyani, I. (2010). Restrukturisasi dan penghapusan kredit macet. PT. Elex Media Komputindo.

Hasibuan, M. S. P. (2009). Dasar-dasar perbankan. PT. Bumi Aksara.

Hassan, M. K., \& Rashid, M. (Eds.). (2018). Management of islamic finance: Principle, practice, and performance. International Finance Review Series, 19. Emerald Publishing Limited.

Jabeen, U. A. (2019). Factors affecting on farmers' indebtedness and suicide - A study in Nalgonda District of Telangana State In India. European Journal of Business, Economics and Accountancy, 7(1), 52-61. Retrieved from http:// www.idpublications.org/ejbea-vol-7-no$1-2019 /$.

Khairi, M. (2018). Dampak pinjaman rentenir terhadap pendapatan pedagang pasar tradisonal di Pasar Pagi Pulo Brayan Bengkel. Skripsi. Fakultas Ekonomi dan Bisnis Islam UIN Sumatera Utara.

Lubis, A. N., Sadalia, I., Fachrudin, K. A., \& Meliza, J. (2013). Perilaku investor keuangan. USU Press.

Lubis, R. (2017). Agama dan perdamaian: Landasan, tujuan, dan realitas kehidupan beragama di Indonesia. PT. Gramedia.

Mangunwijaya, Y. B. (1982). Sastra dan religiusitas. Sinar Harapan.

Nasar, M. F. (2018). Capita selecta zakat: Esei-esei zakat aksi kolektif melawan kemiskinan. Gre Publishing. 
Nofsinger, J. R. (2005). The psychology of investing $\left(2^{\text {nd }}\right.$ Ed.). Pearson PrenticeHall.

Pandey, B., Bandyopadhyay, P., \& Guiette, A. (2019). Impact of different sources of credit in creating extreme farmer distress in India. Benchmarking: An International Journal, 26(6), 16761691.

Parlina, Y. (2017). Praktik pinjaman rentenir dan perkembangan usaha pedagang di Pasar Prapatan Panjalin Majalengka. Inklusif, 2(2), 125-150. doi: 10.24235/ inklusif.v2i2.1938.

Rahmatullah, I. (2015). Aset hak kekayaan intelektual sebagai jaminan dalam perbankan. Deepublish.

Ramadhan, M. (2018). Politik ekonomi islam dalam narasi pembangunan nasional. LKiS.

Rinda, R. T., \& Aminda, R. S. (2020). Perilaku rentenir dan kegiatan sosial ekonomi: Studi kasus di Bogor. Inovator: Jurnal Manajemen, 9(1), 4954. doi: 10.32832/inovator.v9i1.3015.

Rivai, V., Veithzal, A. P., \& Veithzal, A. P. (2014). Credit management handbook. Rajawali Press.

Robbins, S. P., \& Judge, T. A. (2015). Perilaku organisasi $\left(16^{\text {th }}\right.$ Ed.) (R. Saraswati \& F. Sirait, Trans.). Salemba Empat.

Sarimatua, Y. R., \& Husaini, A. (2017). Peran psychological factors terhadap pengambilan keputusan finansial (Studi kasus pada perusahaan Kalrez Petroleum (Seram) Ltd.). Jurnal Administrasi Bisnis (JAB), 51(1), 105114. Retrieved from http://administrasi bisnis.studentjournal.ub.ac.id/index.php/ jab/article/view/2113.

Siahaan, M. (2015). Rentenir penolong pedagang kecil?. PT. Elex Media Komputindo.

Sibarani, B. (2002). Rentenir. Jurnal Hukum \& Pembangunan, 32(4), 411-423. doi: 10.21143/jhp.vol32.no4.1353.
Siboro, I. K. (2015). Rentenir (Analisis terhadap fungsi pinjaman berbunga dalam masyarakat Rokan Hilir Kecamatan Bagan Sinembah Desa Bagan Batu). JOM Fisip, 2(Oktober), 115. Retrieved from https://www.ejurnal.com/2016/03/rentenir-analisisterhadap-fungsi.html.

Sudarsono, H. (2003). Bank dan lembaga keuangan syariah, deskripsi dan ilustrasi. Ekonisia.

Suhendi, H. (2005). Fiqh muamalah. PT. RajaGrafindo Persada.

Sugiyono. (2018). Metode penelitian kuantitatif, kualitatif, dan R\&D. Alfabeta.

Sula, M. S. (2004). Asuransi syariah (Life and general): Konsep dan sistem operasional. Gema Insani.

Supramono \& Putlia, N. (2010). Persepsi dan faktor psikologis dalam pengambilan keputusan hutang. Jurnal Keuangan dan Perbankan, 14(1), 24-35. Retrieved from http://jurnal.unmer.ac.id/index. php/jkdp/article/view/947.

Suryanto. (2017). Faktor bias psikologis dalam pengambilan keputusan hutang. Fakultas Ilmu Sosial dan Ilmu Politik Universitas Padjadjaran. Retrieved from http://pustaka.unpad.ac.id/wp-content/ uploads/2015/06/02-faktor-biaspsikologis-dalam-pengambilankeputusan-hutang.pdf.

Suryono, A. N. R. P., Wijaya, M., \& Demartoto, A. (2015). Perilaku ibu rumah tangga pemakai kredit barang keliling (Mindring: Studi kasus pada ibu rumah tangga pemakai kredit barang keliling mindring di Dukuh Pundung Tegal Sari Desa Manjung Kecamatan Sawit Kabupaten Boyolali). Jurnal Analisa Sosiologi, 4(2), 60-74. doi: 10.20961/jas.v4i2.17438.

Suyatno, T. dkk. (2007). Dasar-dasar perkreditan. PT. Gramedia Pustaka Utama.

Untung, B. (2005). Kredit perbankan di Indonesia. Penerbit Andi.

www.pasuruankab.go.id. 